\title{
Destructive nature of manipulative content, created by leaders of totalitarian pseudo- religious cults
}

\author{
Ivan Tretyakov ${ }^{1, *}$ \\ ${ }^{1}$ Humanitarian Institute, The Higher School of Law and Forensics, Peter the Great St. Petersburg \\ Polytechnic University, 195251, Polytechnicheskaya, 29, Saint-Petersburg, Russia
}

\begin{abstract}
Purpose of the study is the analysis characteristics of the manipulative content, created by members of the totalitarian pseudoreligious groups, as well as the consideration of the manipulative techniques, which the criminals use to destructively influence both individual and social consciousness in pursuit of achieving their goals, constitutes the purpose of this study. The materialistic theory of knowledge, as well as the fundamental principles of philosophy and the legal theory, formed the methodological frameworks of this work. The theoretical principles of psychological and sociological knowledge were based on the concept of a systematic (holistic) study of a personality from the holistic (gestalt) standpoint. The manipulative content, which the members of the totalitarian pseudo-religious groups post on social networks, evidently shows all signs of the hidden psychological impacts aimed at both conscious and unconscious components of the human psyche. Those who create such content actively use the resources of the well-known search engines, adapting them to their specific needs. When rites and ceremonies are performed, manipulative in-fluences are mixed in nature (being verbal, visual, and kinesthetic) and are deeply traumatic for the participants' psyche. While sustainable development is impossible without creating a safe environment in the broadest context.
\end{abstract}

\section{Introduction}

The informational constituent of religious relations attracts close attention of crime, extremist, and terrorist groups. In this Study the author considered the groups, where the criminals proficiently speculated on the religious issues, interpersonal and intrapersonal conflicts, manipulating the feelings of the believers, and imitating their adherence to appropriate rites and ceremonies, or mystical practices, engaged in activities incompatible with the current legislation. The victims of pseudo-religious cults and authoritarian manipulators face such problems as humiliation, deception, extortion, exploitation, spiritual slavery, total socio-psychological alienation, and persistent loss of mental health - and these are just a few of the troubles that can happen to them.

* Corresponding author: mail@tretyakov.su 
The problem we discussed has a long history. Over the centuries the criminals tend to use the religion as a specific tool for enrichment, where all beliefs, prejudices, traditional religions, human vices (both explicit and hidden), ambitions, ideologies, and aspirations for political and economic domination are mixed [1-4]. The most resonant crimes in this area, associated with mass killings and suicides, were related to the activities of so-called religious extremists, terrorists, etc., the most famous examples being D. Jones and «People's Temple», D Koresh, and «The Branch of David», L. Jure and «The Temple of the Sun», S. Asahara and «Aum-Senrikyo», M. Applewhite and «Heaven's Gate», K. Mwerinda and «The Movement for the Revival of the Commandments of God», Islamist suicide bombers - supporters of «Al-Qaida» and other similar structures. The world media cover at least ones per year another bloody action committed by a religious fanatic or a group of such fanatics [5-9], or a sex scandal, which involves paedophiles, sadists, and human traffickers [10-12]. Professor Mark Juergensmeyer, a well-known sociologist and specialist in interethnic relations, shows in one of his works, that some radical forms of new religious mindset are the result of the religious nationalism (extremism), i.e. the response of ethnic groups and communities to the process of globalization. But no matter how different such crimes may seem, at first sight, their major purpose is always the pursuit of enrichment [13].

However, we have to remember that no matter how different such crimes seemed, at first sight, their major point, which was always quite obvious, was the financial constituent; in all such cases, we find the pursuit of certain shadow players (the puppeteers) for enrichment. Globally the overwhelming majority of illegal acts are overtly mercenary, and the negative manifestations of unhealthy religious relations are, unfortunately, no exception [14-16]. The exposed phoney prophets gained not less popular than the most odious leaders of the forbidden sects (rapists, murderers, child molesters).

In recent international scientific literature, the authors, for reasons of tolerance and political correctness, normally tend to use such term as the New Religious Movements (NRM). There are a lot of law-abiding, non-violent citizens among the followers of the new occult, mystical, teachings, and postmodern concepts, while a certain percentage of active followers being overt criminals. We fully share the position of those scientists who have a comprehensive approach to this issue, avoiding a biased attitude, or any one-sided tendency to blame all NRM followers $[17,18]$.

The criminals of the 21 st century, who act under the guise of missionaries, preachers, gurus, or spiritual mentors are highly professional. They resort to deception or breach of trust with a wide range of means and techniques, such as persuasion, hypnosis, threats/intimidation (mental violence). But it is the manipulation technologies that are the most efficient and widespread.

Once a victim joins a sect, the organizers do their best to kill his/her moral and ethical attitudes and form emotional dependence on the criminal leader (guru) or the most influential members of the group [19-21]. Such manipulations deprive mentally competent people of the ability to act on their own, turning them into demotivated creatures. The scope of their interests dramatically degrades, with the progressive destruction of the goal-setting ability. Further on, new incentive functions, crucial motives, conclusions (such as you've made the right choice) are imposed, and a total restructuring of the victims' conceptual hierarchy takes place. The victim's mindset is deprived of flexibility, logic, and criticality. With all consequent, regular manipulative impacts on the cognitive sphere of victims, the criminals get full control over the helpless state of the followers, making the sect members always committed only to the destructive behaviour model [22-24]. Sometimes information on some exotic methods, which the criminal manipulators allegedly use in addition to the traditional, well-known ones (rumours about psychosurgery, electroconvulsive effects, or 
ultrasonic irradiations) can be found on the social networks, but such messages look like being fake news and most likely do not deserve any credibility.

The above circumstances, undoubtedly, reveal that due comprehension of the destructive pseudo-religious content, the manipulative phenomena, which form the basis of the malicious information-psychological impacts, is highly topical today. No doubt that to facilitate the development of the information society, as well as to neutralize the harmful influence of pseudo-religious cults, we would need significant efforts; much more than the simple wording of a problem or the development of some general recommendations. The Government, society, and traditional church should immediately enter into dialogue to work out and set up some worldview concepts, attitudes, positions, i.e. to make proposals for implementing anti-manipulative strategies, as well as to solve a lot of legal problems (in particular, aimed at creating efficient mechanisms to ensure public safety in religious relations, and multi-level protection against criminal information impacts). Moreover, the legislation should be reviewed regularly, and updated with due account of the changes that take place in the post-industrial world, as well as the latest scientific discoveries.

\section{Literature review}

Manipulative content is a major social, cultural, religious, and legal issue. Recent studies on influences of hidden information reveal that there are many techniques in the cyber-space, that can efficiently distort human consciousness and the perception of the surrounding reality within the shortest period [25-29]. Sometimes the technological advances seem to make people more vulnerable rather than protecting them $[30,31]$. It is impossible today to single out any sphere of human life that would be reliably protected from any malicious (or just unwanted) virtual intrusions, being completely free of crime [32-34]. Even a layperson, who addresses a cult leader, should not relax too much since there is no guarantee that no skillfully arranged criminal trap has been set up [35-38].

Among modern criminals who have mastered information technology, a special place is occupied by leaders of pseudo-religious groups. Some criminal leaders of totalitarian cults may be terrorists. Criminals create isolated groups, call for ostracism. Members of religious terrorist groups are beginning to believe that they are defending justice [39-42]. According to criminal leaders, the spread of extremist ideas in the form of hatred, racism, and xenophobia contributes to the unity of youth groups [43-45].

Before highlighting the most characteristic features of closed communities it should be noted that the activities of most members of totalitarian sects are deviant. Numerous scientific studies reveal that any sect is characterized by the following features: the cult of the leader (guru, etc.); the group of people, who are close to the leader and perform the roles strictly assigned to them; the tight discipline with strict sanctions against violators; the lack of any rights for common followers and their complete dependence on the leaders; all sectarians being bound to achieve their goals and solve their problems only within the group [46].

Based on the criminological (criminal-theological) and criminal law approaches, we can clearly state that the leaders of the totalitarian sects (cults) use their informational manipulative and violent methods intentionally, which is against the interests and intentions of the victims, infringing on their honour and dignity. Pseudo-religious crime should be considered as a relatively homogeneous phenomenon, a part of the violent crime [47].

What drives people who being competent turn to semi-legal (sometimes forbidden, destructive and nonconventional) cults, or pseudo-religious groups?

Consider the subjective circumstances. Firstly, it is the boredom, the idle curiosity, the wish to touch something mysterious, exotic, or merely find some new, unconventional sources of information. The second circumstance is the fact that some people get 
disappointed in the traditional religions and family values. They feel frustrated about their lives facing a deep spiritual crisis. They try to overcome their frustration and get away from all problems by finding their soul mates. The third circumstance (however paradoxical it may seem) is the desire of some creatively thinking young people (especially those impulsive, prone to making snap decisions, but with no sufficient knowledge on manipulation) to grasp the true essence of the world. Such people are not satisfied with their role as consumers of information garbage. They want to be thoughtful observers of what is happening around them. Therefore, they address sectarians to get the answers to their questions. The fourth circumstance is an evident manifestation of the age-old prejudices and superstitions, which are still very much alive within all social groups and do not depend on the level of education, intelligence, or life experience of an individual. People still believe that esotericism can save them from all their trials and tribulations [48, 49]. Objective circumstances include effective ways to influence the psyche, as well as content created at a professional level. Destructive content captures the imagination of a person and deprives him of criticism. Victims lose the ability to act on their own [50, 51].

The potential victims (law-abiding citizens) have a very vague idea of such groups, their activities, and possible painful consequences of light-minded behaviour. It is the feature of human nature, that only a few people can foresee in advance the danger that threatens them. Modern people en masse (especially those with a clip mindset) are careless and selfconfident. The motivation of a person is greatly influenced by the fact that the answer to any question can be found on the Internet, but social networks are actively used by criminals.

Apart from being merely dangerous for people, the totalitarian pseudo-religious cults have a distinct destructive effect on the mental health of their followers, which causes a high interest in medical and psychological associations. The so-called disease of adaptation, which is characteristic of the sectarians, is the result of the dysfunctional role contacts, pressure from informational manipulative content, and the methods of gross mental violence. Furthermore, quite often the specialists use such term as blinkered consciousness (also known as tunnelling) for the sectarians, extremists, terrorists, etc. After staying with a totalitarian sect for a long time, the victim experiences the following symptoms - ego stress symptoms (the victim feels guilty, ashamed, disgusted, especially if there were violent sexual contacts); situational phobias, hypochondria, emotional exhaustion and subdepression, demotivation, isolation and alienation, insomnia, problems with intellectual activity, and inability to work efficiently $[52,53]$.

Before communicating with NRM participants, all interested parties should carefully read the messages of the group leaders in social networks, collect information about the goals, objectives, and ideology of the members. Police officers need special training, because the behavior of some people (with religious feelings) is not predictable and dangerous. In pseudo-religious groups, there are mentally ill people, users of psychoactive substances, and aggressive criminals, so caution is required [54-57].

Thus, our review of the literature reveals that the activity of criminal groups, which tend to suppress the will, control behaviour, thoughts, feelings, and wishes, manipulate individual and social consciousness leads to serious global problems (i.e. moral, philosophical, informational, and legal ones). The counteraction of destructive religious groups (i.e. all kinds of totalitarian sects) should be considered a real struggle to preserve the human personality, a fight for his/her rights and freedoms, for the ideals of the genuinely democratic society. 


\section{Methodology}

When selecting specific scientific methods, the author took into consideration the following: the goal, the objectives, the particular features of the problem in question, the characteristics of the object of this study. Of all general cognition methods used, the most popular being the analysis and synthesis, as well as the induction and deduction.

From a wide range of specialized techniques, the following methods were used for the study:

- The observation method - observing and collecting information from open sources on the adverse incidents in the field of the religious relations; on the extent and consequences of manipulative impacts performed by the leaders of criminal totalitarian cults (on the example of Scientology community, «Jehovah's Witnesses», followers of Chizuo Matsumoto, Alexander Kurenkov, Andrey Popov - «God Kuzi», Bodhi cult, «White Brotherhood», etc.); on the hierarchy and features of such destructive quasi-communities; as well as on the experience of countering such structures;

- The statistical method to analyze data on the religious and pseudo-religious crime, as well as on the religious extremism

- The institutional method, which enables evaluating socially dangerous activities of pseudo-religious groups in terms of current legislation, with due account of the existing administrative mechanisms;

- The method of content analysis, including the study of 17 criminal cases on crimes committed by the members of destructive pseudo-religious organizations: «The Order of the Way», "The Church of Scientology in St. Petersburg», «St. Michael's monastery», «Christian mission - Family», «Church of Spiritual Enlightenment». Considered in detail some extremist communities, small groups that have declared themselves Satanists, followers of the «Kondratiev sect»;

- The behavioristic (dynamic, behavioural) method, which allows considering intragroup and inter-group connections, interactions of members of the discussed destructive totalitarian cults in terms of incentive-reaction mechanism (e.g. a specific decision taken in response to an emotionally significant event, etc.);

- The sociological methods, i.e. surveys, questionnaires, free interviewing of law enforcement officers (who give their legal and expert assessment), and members of destructive pseudo-religious groups (victims or being guilty of common crimes). It is the sociological methods that (in combination with all of the above mentioned) enable us to identify the most significant general and special features of the manipulative criminal content, to clarify the methods of committing crimes with information technology, to identify specific ways to engage people in groups, and to establish the reasons why people join such structures;

- The experimental psychological method intended for the analysis of the individual and personal qualities of the victims, the accused, etc. (121 people took part in the experiment); We used the well-known all over the world questionnaire MMPI (Minnesota Multiphasic Personality Inventory).

\section{Results}

We studied 17 criminal cases committed by the members of destructive pseudo-religious organizations: "The Order of the Way», «The Church of Scientology in St. Petersburg», «St. Michael's monastery», "Christian mission - Family», "Church of Spiritual Enlightenment». Considered in detail some extremist communities, small groups that have declared themselves Satanists, followers of the «Kondratiev sect». We were able to see that most often criminals are accused of fraud, extortion, causing harm to health, committing 
extremist acts, sexual crimes, as well as creating groups that infringe on the identity and rights of citizens.

In the opinion of the investigators we interviewed, the manipulative criminals are quite calculating and hypocritical, having all evidence of the artistic talent; they skillfully simulate joy and plausibility, imitate simplicity and sincerity in communication, surrounding an individual with the streams of verbal love and adoration. With close emotional contacts, recruiters establish a very trusting relationship with the potential victim (such contacts become two-way, and the interaction turns into pure manipulation). Thus, more often than not, the victim is not a passive dummy, to whom the criminal psychological impact is directed. The subsequent (quite painful and traumatic) informational intervention is inevitable. The aggressive brainwashing (the mental attack) will continue until the victim reaches the state of complete prostration. In the life of a newly minted sectarian, the phase of blind submission begins.

From interviews with police officers, it follows that the head (leader) of a totalitarian sect usually collects reliable information (including compromising information) about the persons with whom he contacts.

The content marketing of the sectarian criminals deserves an additional analysis. The manipulative content is selected on the heart-over-mind principles, i.e. with as many emotional constituents as possible. The presented information never contains dry facts or complicated conflicting conclusions, it can be used in practice. Advice is given consistently, in simple language, and arouses genuine interest in the target audience.

Those who create such content actively use the resources of the well-known search engines (e.g., keyword dictionaries, electronic glossaries, cross-references, auxiliary algorithms, etc.), successfully adapting them to their needs.

The experiment was conducted in several social rehabilitation clinics in Moscow, the Moscow region, and St. Petersburg, and the Krasnodar region from 2015 to 2019. Several people came from the various areas of Russia to Moscow, where they underwent a comprehensive forensic examination. One hundred and twenty-one people took part in the experiment. All participants were victims of criminal pseudo-religious organizations or accused in the same criminal cases (who are at large awaiting trial). We have to clarify that over 600 people were involved in 17 criminal cases altogether, while only 121 agreed to cooperate with the psychologists and answer their questions. The psychological examination was appointed within three months after the initiation of the relevant criminal case. The age of the respondents ranged from 14 to 62 years. The male/female ratio was 1:4. Numerically, single women over 40 years old, with higher education (55\%), dominated; while about $7 \%$ were minors (children or those closely related to adult sectarians). The data on how long respondents are staying is quite remarkable destructive in groups; $49 \%$ of the respondents had been staying with sects from one month to several years (for four years maximum), 39\% - from five to ten years, and $12 \%$ - for over ten years. Every tenth of the surveyed persons had no permanent job, (however none of them complained of any serious material problems), moreover, everyone had housings of their own (fig. 1).

$38 \%$ of respondents reported that shortly before participating in this experiment, they were examined and subsequently treated (for at least one month) in psychiatric clinics. The materials of the relevant criminal cases show that the initial contacts with the said category of individuals were quite tricky since their idea about the outside world was distorted, therefore, psychologists and psychiatrists were invited to the police department at the request of the investigators (for advice). As a result, specialists diagnosed with reactive conditions and recommended their treatment in a psychiatric clinic. Invited experts recorded signs of neurosis, long-term post-traumatic stress disorder in the remaining $62 \%$. (these people were also treated in rehabilitation clinics). According to forensic 
examinations acts, various pronounced cognitive impairments were revealed for $100 \%$ of respondents (i.e., for 121 persons). Furthermore, the experts identified a stable psychological dependence of the majority of destructive group members on their criminal leaders.

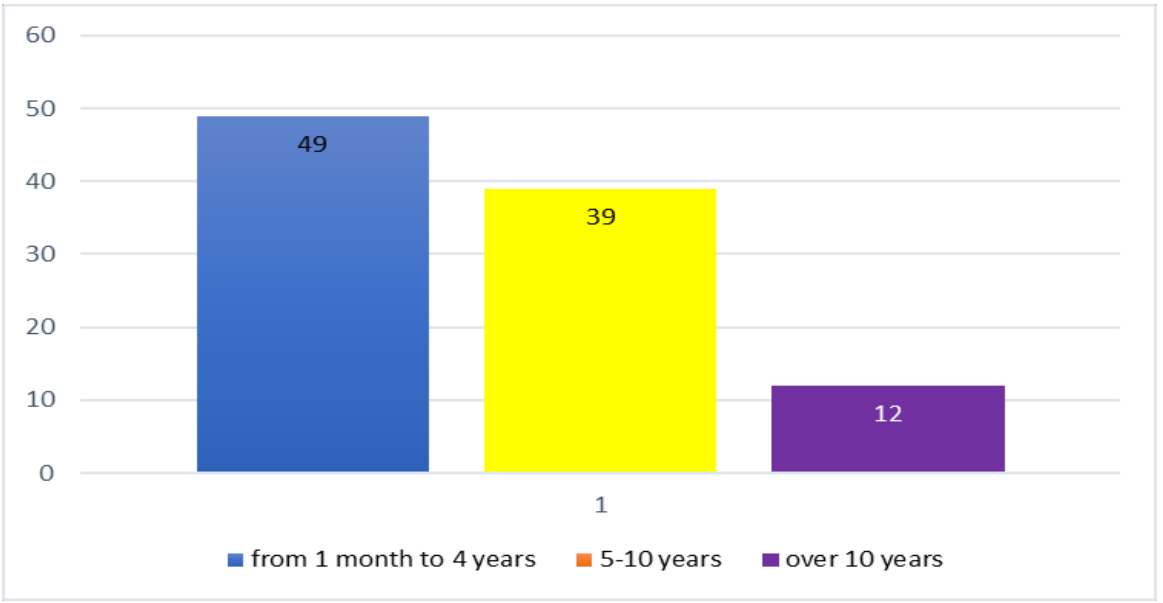

Fig. 1. Length of stay in the destructive group $(\%, n=121)$.

The results of our observations showed that the interpretation of what was happening was still insufficiently adequate for $70 \%$ of the respondents (even after relevant treatment/rehabilitation measures).

With the experimental-psychological (MMPI) and clinical-psychopathological methods (performed with due account of ICD-10 requirements) we singled out three groups of the individuals studied, which are: those with emotional disorders $-45 \%$; those with no signs of mental pathology, still having some pronounced accentuations (i.e. with borderline traits) $30 \%$; those with social phobias, panic attacks, auto-aggression, and signs of a pronounced maladaptation - $25 \%$ (fig. 2 ).

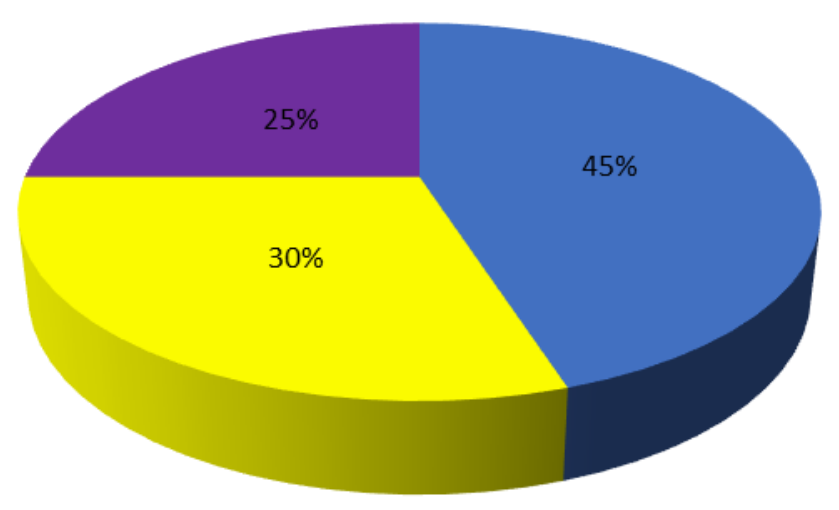

n emotional disorders

no signs of mental pathology, some pronounced accentuations

social phobias, panic attacks, auto-aggression

Fig. 2. The mental state of destructive group members $(\%, \mathrm{n}=121)$. 
The individuals of the second and third groups showed high gradings (vulnerability) in terms of psychopathy $(\mathrm{Pd})$ and psychasthenia (Pt) scale. Most respondents $(90 \%)$ had a very specific combination of psychological features. Thus, we could find such symptoms as persistent deformation of attitude, loss of ego-resources, loss of self-confidence, anxiety, impulsiveness, rigidity, pedantry, superficial judgments, confusion. Psychologists have also noted various manifestations of negative consequences of sensory experience, mainly in the form of depressive disorders. The results of the experiment confirm the psycho-traumatic effect of informational manipulative impacts (with pseudo-religious content) on individual consciousness, and cognitive functions.

\section{Discussion and analysis}

Analysis of available literature sources, indicators of criminal statistics, and criminal cases allow us to conclude that destructive information is widespread in post-industrial society. Moreover, manipulative information flows can destroy both private and public life. At the same time, the media and social networks are full of fake news, violent scenes, and manipulative content. This has already led to the fact that many people's minds are disoriented. The number of conflicts related to aggression and mental disorders is growing. Suicides have reached a critical level [58-61]. Cyberspace has become the territory of endless information wars, a virtual training ground for new manipulative technologies, a place where fundamentally new methods of brainwashing and enslaving the psyche are constantly being created, people, weapons, and drugs are being trafficked. Leaders of criminal groups (criminal communities, etc.) strive to use all available technical achievements of modern science [62].

Our research work confirms the observations of our foreign colleagues that more and more often we can meet leaders of pseudo-religious totalitarian cults that control consciousness. These criminals are very smart and resourceful. Only law enforcement agencies can effectively counter them. Moreover, the state is obliged to stimulate researches on the most topical issues of modern religious law, criminal theology [63].

A significant number of works are devoted to the topic of the relationship between violence and non-traditional beliefs. For example, an FBI consultant, a well-known scientist, and specialist in the social functioning of the new religious movement (NRM), Massimo Introvigne, confirmed that murders (including high-profile mass suicides) are not usually characteristic of such quasi-religious structures. But still, threats, beatings, and humiliations occur from time to time within such groups. Unfortunately, this Italian scientist does not describe the manipulative methods of criminals. His work does not reveal the essence of carefully crafted content that criminal authorities use to attract new subscribers. We fully support Introvigne's claim that sectarian violence remains localized due to their relative marginality of crime. The professionalism of law enforcement agencies plays an important role. This means that if we slightly weaken control over the leaders of such movements, the consequences will be quite serious and tragic [64].

Our data correspond to the observations of foreign colleagues. Criminals who dominate others and create stable pseudo-religious groups are strong, violent psychopaths. Some of them are indifferent to the suffering of others, and the other party seeks to humiliate others, to cause pain [65].

Many authors report the facts, which show that the significant part of non-traditional religions (primarily related to totalitarian cults) has a significant criminogenic and illegal potential. These scientists also reveal numerous examples of criminal activity by pseudoreligious leaders. The researchers, however, focus on physical abuse only, not addressing such issues as manipulation, psychological exploitation, fraud, extortion, etc. [66-68]. According to our observations, in addition to the desire for violence, most pseudo-religious 
leaders are driven by selfishness, vanity, and narcissism. Group leaders seek to enrich themselves. This means that we should never ignore the individual personality characteristics of criminals, their motives. We have studied publications about Islamic fundamentalists who seek to create a quasi-state. These works demonstrate a clear link between politics, religion, and terrorism. The recruitment of supporters of the "Islamic state" takes place all over the world (including among the native inhabitants of Europe, the United States, Canada, and Russia). Journalists write that the terrorists pose a pseudoreligious group for the study of Islam. But the activity of criminals has nothing to do with religious education $[69,70]$. Work and efforts in this direction are in high demand and are very relevant. We must not agree with those authors who do not draw a clear line of demarcation between Islam as a world religion and pseudo-religious terrorism.

The standpoint of some liberal religious cult experts [71, 72], who state that we should never consider specific non-traditional religious movements exclusively through the lens of violence, with no convincing evidence at hand, deserves special attention. Unfortunately, in many cultures, there are strong stereotypes and people traditionally view representatives of another religion (another worldview) as enemies. The authors, of course, are right when they say that a person cannot be recognized as a criminal before trial. At the same time, we do not agree that techniques such as brainwashing, programming, and deprogramming are unscientific or speculative concepts. We regret the position of those authors who deny indisputable facts, for example, that some representatives of non-traditional religious movements use harmful manipulative influences together with brainwashing technologies.

Many researchers [73] insist that the members of antisocial cult pseudo-religious groups have predominantly obsessive-compulsive personality disorders. Our data reveal that we cannot fully agree with such a position. The point is that the majority of the totalitarian cult followers are criminal induced victims. While the aggressive, disinhibited, and hard to curb their instincts (impulses) ones belong to the illegal leader type. When a kind of addictive behaviour, e.g. associated with a deep psychological dependence on the manipulator, aggressor, etc., is being formed, some less pronounced manifestations of the impulse control disorder can appear and (to a certain extent) develop. Moreover, we fully confirm the observation of colleagues that many members of such organizations have sadomasochistic complexes (in the broad sense of the word).

We care about the future of our respondents; therefore, we will go on working in this direction. In the light of the preceding, it is entirely appropriate to refer to the publication of C.M. Cusack, who overviewed the conversations and interviews with people who left NRM. We can confirm the scientist's opinion about the presence of victims of the Stockholm syndrome in the clinical picture. Usually, former adepts do not feel anger and aggression towards other followers of the cult [74], while there are often signs of emotional stress, emotional burnout.

New (non-traditional) religious movements keep on growing; and we agree with those scientists who continuously warn the public of the danger of such growth, who proved that even a seemingly harmless interference in the psyche, and individual consciousness would always ruin human health and psyche [75].

\section{Conclusion}

The participation of an individual in the public and religious life should be free from any destructive manipulations, external dictatorship, and informational threats and speculations. Religious (pseudo-religious) feelings, together with all kinds of superstitions and prejudices, deviations and pathological ideas, criminal intentions, etc. are an integral part of human life, moreover, these psychological and socio-psychological phenomena have a drastic effect on our culture, value orientations, the nature of interpersonal relationships and 
the growth in extremist tendencies. In the event of an adverse scenario, the broad strata of society may well be disoriented by numerous marginal elements.

With careful examination of the pseudo-religious content, we see its manipulative nature and a biased, destructive orientation. The harmful informational and manipulative impacts on the cognitive processes of the recipients result in the fact that the surrounding world of sectarians loses its integrity and orderliness. Such brainwashing of the victims with the harmful content has a pronounces traumatic effect on their psyche. The rituals, rites, and ceremonies, the internal routine, specific training, etc. contribute to a sense of pathological dependence of the victim on the leader (and on the most active members of the group). These actions have all the signs of public danger.

Manipulative content uses the broad capabilities of popular search engines (such as keyword dictionaries, electronic glossaries, cross-references, auxiliary algorithms, etc.). Efforts aimed at improving the quality of content are very fruitful - a new brand is created and successfully promoted in social networks. The most important guidelines for those who develop manipulative content marketing are the results of relevant Internet searches and analysis of the needs of potential victims. Criminals do everything possible to maintain a positive image of pseudo-religious groups. Criminal leaders try to constantly increase the number of their subscribers so that their ideas, attitudes, and stereotypes are spread more intensively.

In the modern information society, there is an ambitious idea of creating effective mechanisms to counter destructive manipulative information technologies. This idea has every chance of success. The consolidation of well-known and influential politicians, cultural figures, statesmen, the Church, and civil society can prevent the spread of violence, extremism, and pseudo-religious crime. An international discussion platform should convey an important message to the public: intrusions into the human mind for criminal purposes deserve the harshest criminal punishment, not a liberal attitude.

\section{References}

1. A.V. Grinëv, Sexuality \& Culture 22(4), 1340-1360 (2018) https://doi.org/10.1007/s12119-018-9529-Z

2. S.V. Kulik, T.A. Baranova, K.N. Bylya, M.N. Sosnina, IOP Conf. Series: Earth and Environmental Sci. 302, $012072 \quad$ (2019) https://doi.org/10.1088/1755$\underline{1315 / 302 / 1 / 012072}$

3. A.S. Matveevskaya, S.N. Pogodin, Bull. of St. Petersburg Uni. Philos. and Confl. Stud. 33(1), 115-118 (2007) https://doi.org/10.21638/11701/spbu17.2017.112

4. D.S. Bylieva, V.V. Lobatyuk, T.A. Nam, IOP Conf. Series: Earth and Env. Sci. 337, 012048 (2019) https://doi.org/10.1088/1755-1315/337/1/012048

5. A.C. Safonova, Theories and problems of political research 5(5A), 208-218 (2016)

6. B. Saul, Research Handbook on International Law and Terrorism (Edward Elgar Publishing, 2020)

7. M. Sardoc, Critical Stud. on Terrorism 13(1), 166-174 (2020) https://doi.org/10.1080/17539153.2019.1675939

8. A.A. Vicina, Internat. sci. j. «Symbol of science» 5-2 (2016) https://cyberleninka.ru/article/n/totalitarnye-sekty-v-ssha

9. K. Knott, B. Lee, J. Politics, Religion \& Ideology 21(1), 1-23 (2020)

10. H. Dayan, Aggress. and violent behav. 41, 25-31 (2018) https://doi.org/10.1016/j.avb.2018.04.004 
11. S.J. Palmer, Religion, Gender, and Family Violence, 146-162 (2018) https://doi.org/10.1163/9789004372399_009

12. A.I. Zygmont, Relig. stud. 2(18), 61-80 (2018) DOI:10.23761/rrs2018-18.61-80

13. M. Juergensmeyer, Critical Rev. 31(1), 102-112 (2019) https://doi.org/10.1080/08913811.2019.1565737

14. A.L. Dworkin, Religious studies 2(18), 81-87 (2018) DOI:10.23761/rrs2018-18.81-87

15. Z.R. Salaev, Sci. portal of the Ministry of internal Affairs of Rus. 4(48), 85-88 (2019)

16. V.A. Silantieva, N.I. Valueva, World of politics and sociology 4, 148-152 (2019)

17. J.G. Melton, The J. of Altern. and Emer. Relig. 21 (4), 88-95 (2018) https://doi.org/10.1525/nr.2018.21.4.88

18. B. Zeller, Theol. Librar. 13(1), 38-49 (2020) https://doi.org/10.31046/tl.v13i1.564

19. Yu.S. Fedotov, Bulletin of the Leningrad state Uni. named after A. S. Pushkin 3, 245255 (2018)

20. Yu.A. Lapunova, The works of sci. of the Rus. Academy of advocacy and notaries 4(47), 61-70 (2017)

21. B. Li, H. Ji, B. Fan, J. of Advances in Edu. and Philos. 3(3), March, 138-141 (2019) DOI:10.21276/jaep.2019.3.3.11

22. A.A. Bakin, V.Ya. Dobritsky, K.A. Mozhar, World of politics and sociology 9, 109116 (2016)

23. D.A. Ryasov, Bulletin of the Krasnodar Uni. of the Ministry of internal Affairs of Rus. 4(38), 24-27 (2017)

24. A.M. Stolyarenko, N.V. Serduk, V.V. Vakhnina, et al., Psychology and Law 9(4), 7589 (2019) DOI: 10.17759/psylaw.2019090406

25. A.V. Fomichev, Communicology: the electronic sci. j. 4, 2, 73-79 (2019)

26. D. Susser, B. Roessler, H.F. Nissenbaum, Internet Policy Rev. 8(2) (2019) DOI:10.14763/2019.2.1410

27. I.L. Tretyakov, In Communication strategies of the information society: proceedings of the XI century. International Scientific-Theoretical Conference (POLYTECH-PRESS, 2019)

28. T.Z. Zarsky, Theoretical Inquiries in Law 20(1), 157-188 (2019) https://doi.org/10.1515/til-2019-0006

29. E.J. Williams, K. Muir, The Palgrave Handbook of Deceptive Communication (Palgrave Macmillan, 2020) https://doi.org/10.1007/978-3-319-96334-1_13

30. F. Calderoni, E. Superchi, Crime, Law and Soc. Change 72, 419-444 (2019) https://doi.org/10.1007/s10611-019-09829-6

31. K. Faust, G.E. Tita, Annual Rev. of Criminology 2(1), 99-122 (2019) https://doi.org/10.1146/annurev-criminol-011518-024701

32. M. Burcher, C. Whelan, Trends in Organized Crime, 1-17 (2017) https://doi.org/10.1007/s12117-017-9313-8

33. D. DellaPosta, Social Networks 51, 148-157 https://doi.org/10.1016/j.socnet.2016.11.005

34. A. Sergi, Australian \& New Zealand Journal of Criminology 52, 3-22 (2018) https://doi.org/10.1177/0004865818782573

35. N.G. Dubovik, Bullet. of the Voronezh Institute of the Ministry of internal Affairs of Rus. 2, 275-279 (2019) 
36. V.V. Gorokhova, N.V. Galanina, Bulletin of the Moscow Uni. of the Ministry of internal Affairs of Rus. 3, 15-17 (2019) DOI: 10.24411/2073-0454-2019-10122

37. A.V. Zhukov, A.A. Zhukova, I.V. Romanov, Bulletin of the TRANS-Baikal state Uni. 23(12), 77-87 (2017) DOI: 10.21209/2227-9245-2017-23-22-77-87

38. I.N. Lebedinets, Actual probl. of Rus. law 10 (83), 168-174 (2017) https://doi.org/10.17803/1994-1471.2017.83.10.168-174

39. J. Gruenewald, B.R. Klein, J.D. Freilich, S. Chermak, Terrorism and Political Violence 31 (3), 516-535 (2019) https://doi.org/10.1080/09546553.2016.1253563

40. M._Pfundmair, Behav. Sci. of Terrorism and Political Aggression 11(2), 1-15 (2018) https://doi.org/10.1080/19434472.2018.1443965

41. D. Ren, E.D.Wesselmann, K.D. Williams, Current Opinion in Psy. 19, 34-38 (2018) https://doi.org/10.1016/j.copsyc.2017.03.026

42. F. Miller, Critic. Stud. on Terrorism 12(2), 185-209 (2018) https://doi.org/10.1080/17539153.2018.1522944

43. K. Jasko, D. Webber, A.W. Kruglanski, M. Gelfand, et.al. J. of Personality and Soc. Psy. 118(6), 1165-1187 (2020) https://doi.org/10.1037/pspi0000198

44. A. Kende, P. Krekó, Current Opinion in Behav. Sci. 34, 29-33 (2020) https://doi.org/10.1016/j.cobeha.2019.11.011

45. K. Van den Bos, Social Psychology and Justice (Routledge, 2020) https://doi.org/10.4324/9781003002291

46. S.S. Galakhov, Scientif. portal of the Ministry of internal Affairs of Rus. 4(48), 24-29 (2019)

47. S.A. Mustafayeva, Communicology: an electr. sci. j. 4(4), 126-131 (2019)

48. E.G. Aniskina, N.E. Mullakhmetov, Bullet. of the Saratov state law Academy 3(128), 160-170 (2019)

49. A.V. Polschykov, A.V. Latyshev, Bullet. of the Voronezh Institute of the Ministry of internal Affairs of Rus. 1, 264-273 (2020)

50. V.V. Osipova, State administration, Electr. Bullet., $70 \quad$ (2018) https://cyberleninka.ru/article/n/ponyatie-netraditsionnye-religii-v-obschestvennopoliticheskom-diskurse-1990-2010-h-gg

51. Yu.M. Khakimova, Electr. sci. j. «Penza psychological Bulletin» 2 (9) (2017) https://cyberleninka.ru/article/n/problema-obmana-kak-psihologicheskogo-fenomena. DOI:10.17689/psy-2017.2.9

52. J.R. Meloy, Contemporary Psychoanalysis 54, 64-83 (2018) https:// doi.org/10.1080/00107530.2017.1414577

53. K.A. Mozhar, O.E. Blokhina, Legal sci.: history and modernity 2, 103-112 (2017)

54. M.P. Bratina, K.M. Carrero, B. Kim, A.V. Merlo, Police Practice and Research 21 (3), 279-296 (2020) https://doi.org/10.1080/15614263.2018.1484290

55. T. Frederick, C. O’Connor, J. Koziarski, A Critical Rev. of Frames, Terminology, and $\begin{array}{llllll}\text { Definitions. Victims \& Offenders 13, (8), 1037-1054 (2018) } & \end{array}$ https://doi.org/10.1080/15564886.2018.1512024

56. R. Grassi, F. Calderoni, M. Bianchi, A. Torriero, Social Networks 56, 23-32 (2019) https://doi.org/10.1016/j.socnet.2018.08.001

57. J.D. Wood, A.C. Watson, Policing and Society 27 (3), 289-299 (2017) https://doi.org/10.1080/10439463.2016.1219734

58. E. Bienvenue, Intern. Affairs 96, (2), 525-527 (2020) https://doi.org/10.1093/ia/iiaa018 
59. R. Condorelli, $\quad$ Springerplus $\quad 5, \quad 374 \quad$ (2016) https://www.ncbi.nlm.nih.gov/pmc/articles/PMC4807205 doi: 10.1186/s40064-016$1799-\mathrm{Z}$

60. E. Humprecht, Information, Communication \& Society 22 (13), 1973-1988 (2019) https://doi.org/10.1080/1369118X.2018.1474241

61. M. Ni ${ }_{2}$ Y. Kim, I. McDowell, S. Wong, et.al., Australian \& New Zealand J. of Psychiatry 54(3), 232-243 (2020) https://doi.org/10.1177/0004867419899165

62. D. Bright, J. Koskinen, A. Malm, J. of Quantitative Criminology 35, 237-258 (2018) https://doi.org/10.1007/s10940-018-9379-8

63. S.A. Johnson, S. Weitzman, The FBI and Religion: Faith and National Security Before and After 9/11. (University of California Press, 2017) https://doi.org/10.1525/california/9780520287273.001.0001

64. M. Introvigne, J. of Religion and Violence 6(3), 315-327 (2018) https://doi.org/10.5840/jrv20186360

65. E. Garcia-Sancho, J.M. Salguero, P. Fernandez-Berrocal, Scandinav. J. of Psy. 58, 1, 43-51 (2017) https://doi.org/10.1111/sjop.12331

66. L. Frisk, J. of Religion and Violence 6(3), 328-345 (2018) https://doi.org/10.5840/jrv20191961

67. E. Irons, The J. of CESNUR 2(1), 33-57 (2018) https://doi.org/10.26338/tjoc.2018.2.1.3

68. C.L. Wessinger, The FBI and Religion: Faith and National Security Before and After 9/11 (University of California Press, 2017) https://doi.org/10.1525/california/9780520287273.003.0013

69. M. Fadel ${ }_{2}$ J. of Politics and Society 31 (1), 83-94 (2019) https://doi.org/10.1080/08913811.2019.1565733

70. N. Saiya, Terrorism and Political Violence 31(2), 204-223 (2019) https://doi.org/10.1080/09546553.2016.1211525

71. R. Moore, The Oxford Handbook of New Religious Movements, II (Print Publication Subject: Religion, New Religions, 2016) DOI: 10.1093/oxfordhb/9780190466176.013.13

72. R.M. Worley, Theory in Action 12(3), 173-178 (2019) DOI:10.3798/tia.19370237.1925

73. F. Rahmani, A. Hemmati, S.J. Cohen, J.R. Meloy, International Journal of Applied Psychoanalytic Studies 16(4), 258-273 (2019) https://doi.org/10.1002/aps.1634

74. C.M. Cusack, Handbook of Leaving Religion (Brill, 2019) https://doi.org/10.1163/9789004331471_020

75. K. Lee, Alternative Spirituality and Religion Rev. 10(2), 156-170 (2019) https://doi.org/10.5840/asrr2019112562 